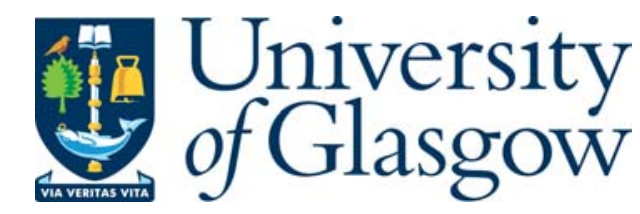

Coll, R. (2007) Student teachers' perception of their role and responsibilities as Catholic educators. European Journal of Teacher Education 30(4):pp. 445-465.

http://eprints.gla.ac.uk/3794/

Deposited on: 30 October 2007 


\title{
Student teachers' perception of their role and responsibilities as Catholic educators
}

\author{
Roisín Coll $^{\star}$ \\ University of Glasgow
}

This article is concerned with 26 primary and secondary student teachers' early perception of themselves as Catholic educators in Scotland. It analyses their perspectives on what it means to be a Catholic teacher, what is expected of them by the Church and what motivated them to choose this particular career path. Discussion of these issues reveals an astute awareness of their role in the Catholic sector but a deep apprehension about their ability to succeed in fulfilling this. Their religious biographies and identities highlight much about the Scottish context of which they are a part, yet their responses to faith indicate differing levels of confidence in teaching, particularly with regard to the content of the Religious Education curriculum which they are expected to implement. The challenge these students present to the major stakeholders in Scottish education is to provide them with adequate support in developing their own faith - and knowledge and understanding of it-in order to enable them to carry out their role as Catholic teachers effectively within the state-funded system.

Cet article se base sur 26 instituteurs et professeurs en formation et leur auto-perception comme formateurs catholiques en Ecosse. L'article analyse leur compréhension de ce que veut dire être professeur catholique et de ce que l'Eglise attend d'eux ainsi que les raisons de leur choix particulier de cette profession. La discussion qui s'ensuit révèle une comréhension pointue de leur rôle dans l'éducation catholique ainsi qu'une inquiétude marquée de ne pas être à la hauteur de cette tâche. Leurs biographie et identité religieuses révèlent clairement le contexte écossais dont ils font partie, quoique leurs différentes réponses devant la foi ne manifestent pas le même niveau de confiance en tant que professeur surtout à l'égard du curriculum de l'enseignement religieux qu'ils sont censés maîtriser. Le défi, présenté par ces étudiants aux intéressés de l'éducation écossaise, est de leur apporter le soutien nécessaire au développement de leur foi, à sa connaissance et à sa compréhension afin qu'ils puissent bien remplir leur vocation d'enseignants catholiques dans l'enseignement public.

Dieser Artikel handelt um die anfaengliche Einschaetzung von 26 Referendaren der Grund- und Hoeherenschulen ueber sich selbst als katholische Paedagogen in Schottland. Er analysiert ihre Perspektiven darueber, was es fuer sie heisst ein katholischer Lehrer zu sein, was die Kirche von ihnen erwartet und was sie motiviert hat diesen beruflichen Werdegang auszuwaehlen. Diskussionen ueber diesen Themen zeigen eine aufschlussreiche Bewusstheit ihrer Rolle im

${ }^{\star}$ Corresponding author: Department of Religious Education, Faculty of Education, University of Glasgow, 11 Eldon Street, Glasgow, Scotland, G3 6NH. Email: r.coll@educ.gla.ac.uk

ISSN 0261-9768 (print)/ISSN 1469-5928 (online)/07/040445-21

(C) 2007 Association for Teacher Education in Europe

DOI: $10.1080 / 02619760701664227$ 
katholischen Bereich, aber geleichzeitig verbunden mit einer tiefen Besorgnis dies selbst erfolgreich erfuellen zu koennen. Ihre religoese Biografien und Identitaeten sagen viel aus ueber die schottischen Umstaende dem sie angehoeren. Dabei zeigen die Schwankungen in ihren Antworten, in Punkto Glauben, unterschiedlichen Grad an Vertrauensniveau zur Lehrtaetigkeit, besonders in Bezug auf den Inhalt des Lehrplans aus dem Religionsunterrichts, den man von ihnen zu leisten erwartet. Die Herausforderung, die diese Studenten den HauptInteressensvertreteren der schottischen Bildung darlegen, ist ihnen die entsprechende Unterstutzung zu bieten, ihren eigenen Glauben zu entwickeln-und das Wissen und das Verstehen darueber-um ihnen zu ermoeglichen, ihre Rolle als katholische Lehrer innerhalb des staats finanziertem Bildungssystem effektiv durchzufuehren.

El artículo constituye un estudio de veinte-seis individuos que quieren ser profesor(a) o maestro(a) y sus percepciones instintivas de ellos mismos como formadores Católicos en Escocia. Esta es el análisis de sus perspectivas sobre la significación de ser un profesor Católico, las expectaciones de la Iglesia Católica, y las razones por qué están inspirado por esta carrera específica. Una discusion de esos asuntos no solo revela un conocimiento astuto de sus papeles en el sector Católico pero tambien una aprensión muy profunda de su capacidad tener éxito y realizar sus papeles y tareas. Sus identidades y biografías religiosas subrayan mucho el contexto escocés en que ellos participan, sino la variedad de sus respuestas a la fe ilustra distintas calidades de confianza para enseñar, especialmente con respecto a lo que está incluido en la curricula de la educación religiosa que tienen que enseñar. El desafío que esos estudiantes presentan a los que estan encargado de la educación Escocésa es proveerles-a los estudiantes-de apoyo suficiente para desarrollar sus propias fes-y conocimiento y entendimiento de ella-para permitirles cumplir eficazmente sus papeles como profesores(as)/maestros(as), especialmente dentro de un sistema que depende de fondos del Estado Civil.

\section{Introduction}

Good teaching is charged with positive emotion. It is not just a matter of knowing one's subject, being efficient, having the correct competencies or learning the right techniques. Good teachers are.... passionate beings who connect with their students and fill their work and their classes with pleasure, creativity and joy... (Hargreaves, 1998, p. 835)

Education reform continues to spread throughout the world like a policy epidemic (Levin, 1998), where powerful agents and stakeholders contribute to the multitude of interrelated ideas that ultimately determine what educators and scholars will not only $d o$, but affect who they are (Ball, 2003). In recent years in the UK there has been criticism over a tendency to promote a 'technicist' or 'performative' model of reform where teacher education programmes have focussed on producing educators expected to 'deliver' 'centrally packaged decisions' that ignore or undermine the importance of educators as unique individuals with existing experiences, perspectives, insights and personalities. Ball has advised of the dangers of this continued trend, where practitioners are expected to 'set aside beliefs and commitments and live in an existence of calculation' and where they are presupposed to be organising themselves in 'response to targets, indicators and evaluations' (2003, p. 215). Ball showcases the individual teacher and considers the effect that educational change 
can have on one's social identity, referring to the 'struggle over the teacher's soul' (Ball, 2003, p. 217). He is not alone with his concerns, as there is a wider and rapidly-growing interest in what might be termed the inner life of the teacher and how this relates to the effectiveness of schools (Voiels, 1996; Dadds, 1997; Mills et al.,2004).

In this paper, the focus is on a related area concerned with the perceptions of Roman Catholic students embarking on a teaching career. The debate about faith schools is wide-ranging and it too has generated much educational argument in recent years in the UK, much of which presses its claims to public attention on the current expansion of such schools (Short, 2002). The debate rarely focuses, however, on the role of the teacher and the self-constructs of those who are professedly members of the faith community in which they teach. This is a poorly understood part of the mosaic of faith education in Britain today.

Scotland has a unique position with regard to faith schools since the state primary and secondary establishments falling into that category are all (with one or two exceptions) Roman Catholic.Unlike its neighbour south of the border, or indeed countries elsewhere, where there are or may be faith schools for a variety of different religions and denominations, Scotland's education system includes denominational schools for those belonging to the Catholic tradition. At present there are Catholic teachers employed in 403 Roman Catholic state schools in Scotland.

\section{The Scottish context}

Much recent research has shown that many student teachers construct their career choice not in terms of professional progression or salary opportunities but in terms of a belief that this work is socially meaningful, challenging and will assist in the transformation of pupils for the good of the individual and of society (Younger et al., 2004). The good of the pupil is held as a high priority by beginning teachers alongside the ambition and desire to connect with the children they teach, in an attempt to make an impact on their lives, and is a highly motivating idealism that encourages committed individuals to enter the teaching profession.

In Scotland, there exist a number of institutions offering students a pathway to teaching in both the primary and secondary sectors through a variety of Initial Teacher Education (ITE) programmes. These include a mixture of four-year undergraduate courses and one-year full-time or two-year part-time postgraduate options. Owing to the rigorous scrutiny of these programmes by the General Teaching Council of Scotland (GTCS) on behalf of the Scottish Executive, and the expectation that all finishing students will have satisfied or exhibited an agreed set of standards prior to probation, (QAA, 2000) the programmes of study on offer from the different institutions have many similarities and, in consequence, students have traditionally chosen an establishment for reasons relating to geographical location or reputation rather than for any real difference to the content of the course. Some ITE institutions do have additional courses on offer, for example Physical Education ITE programmes, which influence the makeup of their intake. However, an institution in 
Scotland offering ITE programmes that contain one significant difference from all others found in Scotland is the University of Glasgow. In 1999, St Andrew's College, by then the single national Catholic teacher education institution in Scotland, merged with the University of Glasgow and the result was the creation of a new Faculty of Education within the university. Recruitment into the major ITE programmes of the faculty inherited some of the responsibilities of the former college and focuses not only on attracting intelligent and capable students with the desire to educate children, but on encouraging Roman Catholic students to embark on teacher education studies which include the Catholic Teachers' Certificate, thus enabling Catholic students to teach in Catholic Schools across the country (subject to statutory approval by their local diocese).

As a result of the 1918 Education (Scotland) Act, Catholic schools in Scotland are fully funded by the state; however, those teaching within them must be approved by the Catholic Church with respect to belief and character. In addition to, but separate from approval, the Catholic Teachers' Certificate indicates that a person is suitably qualified to teach religious education in the Catholic school. No other institution in Scotland provides for this. Catholic students from ITE programmes within other universities can gain the certificate via a distance-learning course, again provided by the Faculty of Education at Glasgow, but this has to be paid for. For these reasons, many students on the ITE courses at Glasgow are Roman Catholic and claim to have the desire to teach in Catholic schools. At present $97.5 \%$ of students completing the four-year undergraduate Bachelor of Education (Primary) degree are Catholic, as well as $68 \%$ of the one-year Professional Graduate Diploma in Education (PGDE) (Secondary) and 65\% of the Professional Graduate Diploma in Education (Primary).

Not without controversy, the state authorities have accepted the Church's role in Catholic Education and supported its involvement in Catholic state schools in Scotland since 1918, working closely with the Catholic Church on a number of education initiatives in recent years (Coll, 2002). Catholic schools operate and are controlled through the structures of local government in exactly the same way as those in the nondenominational sector, with the exception of the employment of staff and the content of the RE curriculum. Unsurprisingly, the institutional Church has a very distinct view of education (see below) and the Catholic schools' sector in Scotland has embraced this. Through the governance of the Bishops'Conference, advised by the Catholic Education Commission(CEC) and supported by the Scottish Catholic Education Service (SCES), the Church claims that it is committed to ensuring that Catholic teachers know, understand and believe in the mission of the Church and its educational philosophy (SCES, 2007). As a result, not only do finishing Catholic student teachers have to prove to the GTCS and the state that they have reached a certain standard of competence with regard to their teaching ability, they must also satisfy the Church that they are worthy and capable of teaching in the Catholic sector, where they will be expected to assist children 'to take ownership of their faith and deepen their relationship with God'. (SOED, 1994, p. 3) 


\section{The Catholic Church's expectation}

The Church considers education to be its concern since, 'as a mother, it is obliged to provide for its children an education in virtue of which their whole lives may be inspired by the spirit of Christ'. (Gravissimum Educationis, 1965, p. 3)

It could be argued that the Catholic Church has a very healthy position with regard to educational provision in Scotland. Enshrined in law, it has jurisdiction over the employment of staff in Catholic schools and the content of the Religious Education (RE) curriculum. Potential teaching staff must satisfy the Church that they are suitable in 'belief and character' (Great Britain Statutes (1918) Education (Scotland) Act) and they are, as a result, subject to a stringent approval process. Anyone teaching RE must be an approved practising Catholic (almost all those teaching in Catholic primary schools fall into this category). In addition, the Catholic Church requires to be assured that all other appointed teachers are committed to the promotion and support of the Catholic school's mission, aims, values and ethos. Approval is therefore required for them also. The process involves a reference from a priest (or for non Catholics, a professional) who can testify to the commitment of the individual-in the case of Catholic staff, to their active faith commitment.

The reason for the approval process originates in the Church's belief that, in addition to being interested in enabling young people to take up roles of leadership and responsibility in society and achieving academic success, education is about forming people of 'conscience' with a 'Christian vision and value system, a concern for their fellow humans and a deep desire to put their talents at the service of others' (Bishops' Conference, 2001, p. 3) The Church believes that the way to achieve this is to ensure that children are exposed to teachers who are committed Catholics themselves, devoted to this mission:

Teaching has an extraordinary moral depth and is one of our most excellent and creative activities. For the teacher does not write on inanimate material, but on the very spirits of human beings. (Sacred Congregation for Catholic Education, 1998, p. 19)

The Church has recognised the continuing decline in the number of religious (a commonly used term for those who are ordained to the priesthood or religious life) working in Catholic schools worldwide and has strongly asserted the importance of the lay Catholic teaching vocation. In Scotland, this is no different. O'Hagan (2006) has focused on the contribution of Religious Orders to Catholic Education in Scotland and the impact of the shift to lay involvement. Indeed, the decline in religious vocations in Scotland has been significant and as a result, with one exception, all Catholic state schools are managed and led by lay Catholics, with only a handful retaining the involvement of religious. In a Vatican document concerned with discussing the role of the Catholic lay teacher, the Church's expectation is clear;

The Catholic educator must be a source of spiritual inspiration...The lay Catholic educator is a person who exercises a specific mission within the Church by living the faith, a secular vocation in the communitarian structure of the school: with the best possible professional qualifications, with an apostolic intention inspired by faith, 
for the integral formation of the human person, in communication of culture, in an exercise of that pedagogy which will give emphasis to direct and personal contact with students.

(Sacred Congregation for Catholic Education, 1982, p. 14).

Vatican II's Declaration on Christian Education unmistakably states the role of the Catholic teacher:

Let teachers realise that to the greatest possible extent, they determine whether the Catholic school can bring its goals and undertakings to fruition. They should, therefore, be trained with particular care so that they may be enriched with both secular and religious knowledge... Bound by charity to one another and to their students, and penetrated by an apostolic spirit, let them give witness to Christ, the unique Teacher, by their lives as well as by their teachings. (Gravissimum Educationis, 1965, p. 8)

It has been argued that the high expectations for the role of Catholic educators can have a counter-productive effect on recruitment (Grace, 2002). However, in Scotland-particularly for the undergraduate four-year course-this has not been the case. There is some anecdotal evidence to suggest that the number of Catholic graduates in Scotland wishing to teach is reaching its limit but the number applying for the undergraduate ITE courses is almost ten times the number accepted to study. It is assumed then that student teachers wishing to teach in the Catholic sector should accept and embrace these expectations and the approval process attempts to confirm that students are indeed committed to this.

\section{Methodology}

The concern of the research at the heart of this paper is with finishing students' perception of what it means to be a Catholic teacher and its implications for them in carrying out their role. The evidence is drawn from individual interviews with 26 Catholic student teachers attending the University of Glasgow, which took place about 12 weeks prior to the completion of their course.

\section{Interviews}

The lightly structured interview was considered most appropriate for this particular study. Using Wengraf's pyramid model (2001, p.63) a number of interview questions were created, governed (see appendix) by overarching research questions in order to produce interview material for analysis. The interviews were lightly (or semi) structured in order to standardise questions while creating a degree of openness of response on the part of the interviewees. 'Interview interventions' (Wengraf, 2001, p. 63) took place when necessary, encouraging further depth to interviewees' responses.

Twenty-six student teachers were interviewed for this project and they came from three of the ITE courses on offer at Glasgow University: the four-year BEd Primary (Hons) Degree, the one-year PGDE (Primary) course and the one-year PGDE (Secondary) course. When selecting interviewees, purposive, criterion sampling 
(Patton, 1990) took place, meaning subjects were selected on the basis of a number of characteristics. For this study all subjects had to:

- be Roman Catholic

- be in their final year of ITE study at the University of Glasgow

- be studying for their Catholic Teachers' Certificate

Nine students were male, and seventeen female. Fourteen were hoping to enter the primary sector and twelve the secondary. This sample was considered appropriate since, as Patton argues, one can learn a great deal more by focusing in depth on a smaller number of interviewees rather than gathering standardised information from a large statistically representative sample. This smaller sample was considered to be 'information-rich' (Patton, 1990, p. 169).

The interview data were coded in order to elicit emerging concepts and to develop categories. Strauss and Corbin's (1998) open coding took place resulting in the researcher grouping similar happenings and responses under a common heading or classification. During this process, data are broken down into discrete parts and examined and then these are compared to find out if there are any similarities or any differences. Happenings that are found to be conceptually similar, or that are related, are grouped into categories.

In discussing these interviews, the focus will be on the circumstances and nature of the motivation of the students to teach in Catholic schools; their understanding of the career on which they are embarking (including the Church's expectation of them) and how they will envisage discharging their responsibility.

\section{Results}

\section{Identity}

Social histories. Within this research, the intrinsic reasons for choosing to teach in a Catholic school were centrally linked to student teachers' biographies and social histories. The research revealed that $88 \%$ of student teachers identified their background as a major reason for their decision to attend Glasgow University and gain their Catholic Teachers' Certificate. A number of students did not give any theological, political or educational reason for their choice. Phrases such as 'obvious sector' and 'natural thing to do' were used, indicating a loyalty and sense of belonging to their community. Some appeared to be unreflective about their position and admitted simply being comfortable in the tradition and that they didn't know any different:

Well, I'm Catholic myself so it wasn't a choice that I would choose the nondenominational sector.

I'm Catholic myself and I've been brought up as a Catholic so it made sense to carry it on.

I've chosen it primarily because I'm a Catholic myself so I don't really know anything else other than that. 
For some it was the inherent value of 'continuing' or 'passing on' the faith and being a part of the community:

Because of my upbringing, I was always at a Catholic school em basically that's what I believe, and obviously I want to go in to a Catholic school and kind of share that and that's just the upbringing that I've had, that's what I see as being normal for me.

I've always been brought up within Catholic Education and I feel it is part of my faith to pass that on.

I'm a Catholic and I see that it's been important to continue that faith.

For others, however, a considered thought process clearly had taken place and they were able confidently to articulate their desire to be a part of the Catholic system:

I'm a committed practising Catholic, I see the value of Catholic Education and, wishing to be a teacher I want to participate in that particular sector

I've been brought up a Catholic and the Catholic ethos in schools that I've seen is one of the main reasons. I think that there is a better quality of Education.

I believe in Catholic Education and its importance for society and I think that Catholic schools are a sign of society that parents should have the democratic right to send their children to whatever school they want and are a reflection of different shades of society and how schools should be in the future.

Catholic schools provide children with a different grounding in education ... and I like making sure that religion is some part of children's lives

This study has revealed then that identity and belonging to the Catholic community is, for some students, justification alone for choosing to study to teach in the Catholic sector. For others, there have been additional reasons, relating to a firm belief in the principles of faith-based education or to personal experience or to a knowledge of its perceived merits. However, a cohort of students admitted that they entered the sector because they simply 'belong to it'. It could be argued that this is not a healthy position, since students may be blinkered in their choice, having failed to consider alternative options. Paradoxically, it could also be perceived as being a very strong position - students have not considered other options because they are so immersed in their tradition and feel strongly about remaining within it.

At this stage an awareness of the historical context in which these students find themselves is crucial. Much has been written about identity in Scotland and in particular that of the Catholic community (Boyle \& Lynch, 1998; Devine, 2000; Bradley, 2004). Although an ethnic minority group in an increasingly secular country, the Catholic community has a significant presence in Scotland and the Church has become a well-established institution (Boyle \& Lynch, 1998). The community has its origins in the survival of the Catholic tradition post-reformation, but the immigration of Italians, Poles, Lithuanians, and Irish has been the major contributing factor. There are a number of Catholic communities in the Highlands and Islands as well as the North East of the country. However, Catholics of Irish 
origins are the largest segment of Scotland's Catholic community and are concentrated around the central belt, particularly in the West. This influx of Irish Catholics had an impact on the education system and as Bradley (2004) argues, the Catholic Schools system was created as a direct result of this.

When the Irish first came to Scotland they were often subjected to much hostility as was their 'alien and often detested faith' (Bradley, 2004, p. 20). The census report of 1871 stated that, 'as yet the great body of these Irish do not seem to have improved by their residence among us; and it is quite certain that the native Scot who has associated with them has most certainly deteriorated. It is painful to contemplate what might be the ultimate effect of this Irish immigration on the morals and habits of the people, and on the future prospects of the country'. (Handley, 1947, p. 321)

Grace (2002) explains that, for many anglophone countries, Catholic schools were 'constructed and constituted as citadels and fortresses for the preservation of the faith in a hostile external environment characterised by a dominant Protestant order, continuing anti-Catholic prejudice and the growing influence of secularisation'. (p. 7) It has been argued that the struggle to survive and thrive in Scotland has resulted in the well-established and lasting identity of this community to the present day. While it has been claimed that social and economic change have led to the integration and acceptance of the Catholic community into Scottish society, there still exists a belief that a struggle against discrimination continues and this has been well documented in recent years (McMillan, 2000). A high proportion of Scotland's students choosing to teach in Catholic schools come from this Catholic community situated in the West-Central belt of the country, including, it should be noted, $85 \%$ of those selected for the purpose of this research.

Faith background. When discussing their religious backgrounds and 'faith biographies', $88 \%$ of respondents revealed their family as having a strong influence on their religious development. It quickly became apparent that many of these students were brought up within the context of a practising Catholic environment where religious observance and promotion of the faith's traditions were normal day-to-day events:

Both my parents, my mother in particular was quite rigorous about her faith...I had that background. There are six in my family and it was all centred around going to Mass, you know. We went to novenas and devotions and it was a very traditional Catholic upbringing.

My mum's family is a strong Catholic family. We always went to Mass as a family and we continue to do that now. My dad wasn't and he became a Catholic when I was young.... and I suppose if your dad is doing something like that it's a good example and model as well for you and even through to now...

My grandfather had a strong influence on me because he was a very faithful man and was just a person who had a wonderful faith and I think that that has really filtered on, and I think that it is a gift and I just hope you know, that I can continue it as best I can...

I've a strong family background...it would just be conversations with my parents that's helped me develop my faith .... and with family friends that are priests .. 
For a very small minority, family was not a major source of influence in terms of faith development and, interestingly, this tended to be the case for students with parents of mixed faith:

I've got a kind of mixed background so em in the home I've got one parent Catholic and one parent is Protestant so because of that it wasn't a really, its not a very religious family.

My mum's side is Catholic and my dad's side is non-Catholic... my mum and gran have a lot of faith but they don't attend mass em my gran's side is Irish so I think that's why I was brought up [Catholic]..my mum and dad never enforced anything ...I didn't have to go to mass.... I just believed in God. That's all I knew about my religion when I was younger, I believed in God and that was it, I didn't believe in anything else.

Alongside family being mentioned by most as having a paramount influence, Catholic schooling also had significant effects on shaping faith, though not all of these were positive. $92 \%$ commented on Catholic schooling having contributed to making an impact on their faith and, of these, $25 \%$ went as far as to say that this was even stronger than their family's influence:

I suppose most of my faith though did come from school. There was a push towards masses and prayer. There was prayer at the start of every class.

Most of my input was from primary school.

It was certain teachers you know who gave you that faith, you know they would refer to it...just the way some were hopeful and trusting, 'Just put your trust in God and it will all work out' and all this kind of stuff...they would maybe make wee comments like that and they weren't RE teachers.

For others, the Catholic school did support or 'back up' what was being said and practised at home and the continuity between school and home was an influential element in itself.

When I experienced the loss of my dad the school chaplain went out of her way to take me out of class and see how I was doing. She was a sister and I'll always remember that.

I always felt that anything that was learned at home or in the parish was reinforced in school...I got a uniform message.

For a small minority of those interviewed (19\%), the experience of Catholic Education at school was not always particularly positive and this will be discussed in the next section.

A further point to note was that $69 \%$ of those interviewed highlighted the connection between home, parish and school when asked about the background to their faith development. Much has been written about the institutional Church's view of the importance of the inclusion of all three elements in a child's education and its stress that the 'partnership between home, parish and school is the best setting for the formation of maturing young people' (Bishops' Conference, 2000, 
paragraph 3). It is considered that this 'triangle' is the bedrock for educational provision. Indeed, when asked about their faith development, the majority of those interviewed commented on how visible and influential these three elements were when growing up:

I've learned from my mum, from the school and em from my Church.

Faith formation? I suppose through the school and I also liked being part of my local Church, being an altar boy, that kind of thing so partly that and my family as well.

From my parents primarily and from school to some extent, to a great extent I would say from school and from my local parish.

\section{Student teachers' views of themselves as Catholic educators}

Role. All of the students were confident and clear when detailing what they believed to be their role as a Catholic teacher. The responsibilities indicated an awareness of the Church's expectation of them; most notably they talked about being a witness to the faith, passing on the faith, helping children in their faith journeys and spreading the Gospel message - all familiar language of the Church:

I think it is very important to give children a faith, something to hold on to and to run in tandem with and to accommodate their spiritual life as well as their educational life.

Em to support children in their faith, to some extent. Unfortunately for a lot of children to initiate them in the faith or at least give them some contact with the Catholic Church which they may not have at home...lead them in daily prayer and hopefully pass on the teachings of the Catholic Church.

To teach the Gospel values through your teaching

Being a role model for the children in school., leading by example, letting them see you as a member of the Church.

To give more of a faith input rather than knowledge about the faith.

I see my role as being a representative of the faith

This apparent understanding of their role, and confidence in articulating it, is perhaps testimony to the input they received during their ITE course. However, only $58 \%$ of the students admitted feeling ready to carry out this responsibility and of these students an awareness of the enormity of the task was very salient.

You're a Catholic teacher. It's not a thirty-five hour week you're a Catholic teacher, it's non-stop like in everything you do.

Yeah. It's a bit scary but I feel more excited about doing it because it is a challenge...

Yeah but...I'm still learning...it's a little bit frightening that these kids are relying on you to learn their faith. 
This was echoed by the remaining $42 \%$, who displayed a clear understanding of their strengths and weaknesses in this aspect of their future careers and showed selfperception when identifying their needs. The strengths that students diagnosed tended to be concerned with their personal characteristics, talking about being witnesses to their faith in the manner in which they communicated through word and action.

I wouldn't say that I'm hugely versed on my faith or anything like that but the whole way you treat each other... that will be the main thing that will come across in my own teaching.

I stopped going to mass myself and its only in the last couple of years, you know with family and everything, that I've started going back. I'm not the greatest Catholic in the world...but I'm an example...

As a Catholic teacher I can foster that ethos within schools, to be open, to be approachable... to consider myself as a Catholic teacher before as English teacher.

What was particularly noticeable was their claimed commitment to their role as Catholic teachers, along with their enthusiasm in this area. Other strengths identified were in relation to their faith backgrounds and what they themselves had learned as they grew up.

Concern. Conversely, a deep apprehension about their own knowledge in the area did arise as a concern for many of those interviewed. While feeling confident in their ability to promote Christian values and ethos, it emerged that $39 \%$ worried about their competence in the transmission of accurate knowledge and about being questioned on aspects of the Catholic Church's teachings:

I think that there is a lot of knowledge that I still have to get, you know....

I do feel that there are a lot of areas that I'm not quite sure about yet....I do feel sort of, I'm not particularly prepared in the RE element of the teaching.

The RE part is still quite daunting to go in and teach RE at the moment ...because it's outwith my subject area.... my area of expertise. In my last placement I was worried because we were doing a lot of work on the Old Testament and trying to get to grips with it and then going into class... but I'll just have to get on with it and stay one day ahead.

This concern relating to knowledge and understanding of the content of the curriculum and a fear of being asked difficult questions was a common occurrence, but some students had already identified methods for coping with this. One student commented on the confidence she had in the support network she had at home and in her parish if she required to seek advice. Some indicated a confidence in the school assisting them in terms of continuing professional development. Others mentioned the belief they had in the strength of their own faith in assisting them in succeeding in their career and indicated the importance of ensuring this was developed. 
[I'll be fine] as long as I'm keeping up with my own spiritual journey and doing my own reading ...

Experience of RE and Catholic education. Thornton et al., (2002) and Younger et al., (2004) have suggested that for many students, the decision to teach is as a result of their own positive experience of schooling. For a number of the students interviewed for this research, the decision to teach in this sector based on positive past experiences of Catholic schooling was not always evident. The experience of the religious dimension to their schooling was not always edifying:

I feel it wasn't really well taught in school, again I think that's very much dependent on the teacher, you know in school I thought that there was very much emphasis on the 'Catholics are right and everybody else is wrong' ... and I think probably that pushed me away from the faith rather than brought me to it.

It was a chore and was kind of frightening. Secondary school was just copying out the Bible so although I was Catholic, I wasn't. I didn't really take my religion seriously then to be honest.

It $[R E]$ was the period which we took registration.

It is clear, then, that although these negative experiences had an effect on the students, they did not deter them from entering the sector or when embarking on a career in teaching. For some it resulted in a determination to contribute to the eradication of the kinds of bad practice they had themselves experienced:

It will teach me to be very wary about the way of teaching Catholicism and religious education, it has to be very balanced teaching, and it has to allow children to wander....

I don't want to be that kind of teacher that just gives pupils Bibles to copy out and just lecture to them about what happened in the gospels. I want to be like the kind of teacher I had one year, the kind that made it exciting...

It's important to note that all of the negative experiences recorded were directly related to lessons - that is the content of the RE curriculum and the manner in which it was taught. However, the positive experiences documented by other students refer mainly to the pastoral nature of the school and the manner in which teachers related to pupils. Examples were given of the care and support of staff during periods of bereavement; encouraging pupils to use their talents to get involved in the religious services or teachers being available for chats where the advice given had its roots in the Christian faith and often included phrases such as 'Trust in God' or 'I'll remember you in my prayers'. This kind of interaction was frequently mentioned and respondents commented on how this 'witness' of teachers to the faith contributed to their own belief:

I've learned a lot you know..... what strength and support you can find in religion and even through school, knowing that you had someone to talk to, knowing that there was a priest or teacher that you could talk to, you think that they didn't have a clue because they didn't' live your lifestyle but they did and they were good. 


\section{Expectations}

Faith development. Respondents in this study were unanimous when indicating the need and desire for additional support in the area of faith development if they were to realise and fulfil their role as a Catholic teacher. For many of them, the Catholic Teacher Formation component of the ITE course that they were completing had already contributed to their development and had whetted their appetites. Some were surprised at how much of a positive effect this had had on their faith and how they were looking forward to learning more and developing it further once in school.

I have found even the last part of the R.E. specialist course...has been really, really important in, in directing me and giving me reasons for things I really didn't know before.

It has strengthened my faith ...you have to make the commitment to it and it has committed me more towards my religion, definitely, or towards the faith, because I feel it sort of, I feel I have to, I want to know more about it.

I think for a lot of people on the course as well, it's renewed their faith, you know, it really has renewed their faith

Interviewees were unsure of the amount of support they would get, but all expected to get some.

Now that I have started I don't want to stop....it's something new to me, to be questioning myself so don't want to stop.

Collaboration. The discussions on this area revealed that the interviewees regarded faith development to be both a personal and yet collaborative activity of teachers. While appreciating that people have very different faith positions and biographies and that personal and private reflection on faith is important for their work, $92 \%$ stressed the need for collaboration to take place when engaging in faith formation.

It would be good if Catholic teachers were involved in it together... it links with the whole idea of being a reflective practitioner... what better atmosphere to do it in that with other Catholic teachers..

I would love to see it as a communal activity because I'm the type of person who really benefits from the support of other people...

You need to have your own personal faith but you also need support from other people.

You should be involved in it as a community but also.... Everyone's at their own stage so it's a personal journey as well.

School support. Within the context of the Probation year-on which all the interviewees would embark once they had completed and passed their coursethere was a clear expectation from the majority of respondents that their school would provide support in terms of faith development for all staff. Interestingly, many 
spoke of this as though they were relying on it and took for granted that this would be catered for in the Catholic school. Sixty-nine per cent expected there to be formal Continuing Professional Development (CPD) structures in place to ensure that the faith of staff was being developed and monitored and that this would take the form of courses provided by the Local Authority, Glasgow University, the Diocese or from SCES.

Hopefully through CPD I will get more information .. it's a big part of Catholic education so I would expect it.

If you could have CPD courses and days to do with it then that would definitely help.

In addition to the formal activities expected to take place, assisting teachers in the development of their faith, all respondents expected there to be an informal undercurrent of support existing too. Those in the secondary sector expected this to come from the RE department in the school and many emphasised the role of the chaplain in supporting them, or the assistance of the local parish. Others commented on the importance of the leadership in the school and how the head teacher should be there to help staff where necessary.

I hope support will come from within the school, like whatever head teacher I'm with, like she's supportive of her teachers or his teachers, developing them...

The overwhelming expectation of support for faith development was noteworthy and with this came a clear desire to respond to such activities and use them to help with the concerns or worries raised regarding their work as Catholic teachers.

\section{Commentary}

These interviews convey an alert analysis in student teachers' perception of what it means to them to be a Catholic teacher. Many respondents displayed a thoughtful understanding of their own ability and of the strengths and concerns that they had with regard to being effective Catholic educators. They were very clear as to what they wanted to achieve and had strong ideals regarding the support they required to realise this. Their desire to succeed as effective faith educators was evident and their articulation of the enormity and importance of this task illustrated how highly valued they consider their role to be.

\section{Identity}

It quickly emerged that 'identity and background' became a significant theme when discussing Catholic education with the student teachers. A firm attachment to the Catholic community, an unequivocal belief that Catholic education is of value and worth, coupled with the majority's positive experience of Church, school and home are all indicative of the impact of religion in their formative years. The commitment to the Catholic tradition that is espoused here is acute, which in itself is revealing though perhaps unsurprising when we appreciate the context in which the majority 
of the respondents find themselves. It is argued here that this commitment can be linked to the position and importance of the Catholic Church in Scotland and its historical narrative. It is recognised that while the institutional Church may be universal, its profile in Scotland is somewhat different to that in any other country, including its neighbour England (Boyle \& Lynch, 1998). Its continued and heightened position within the Scottish press, and public discourse generally, has ramifications for the present Catholic community, a community well aware of the treatment of some of its members' ancestors when they first arrived in Scotland. The concept of a 'ghettoised' community is often referred to by authors on the Irish/ Catholic community in Scotland and although it is accepted that this is no longer the case and that the community has become socially mobile and integrated into Scottish society, the legacy of their struggle remains, resulting in a firm loyalty to the traditions of their faith (Devine, 2000; Conroy, 2001).

It would be hard to detach this narrative from the social biographies of those interviewed. Many indicated from an early stage that they were of Irish or Italian origin, while a large percentage communicated the strict and unflinching devotion of family members to their own faith and the transmission of this to their offspring. It can be said that while respondents' individual faith backgrounds differ quite considerably from one another in terms of their response to the faith input they received when growing up, the similarities in the input they did receive reveal a detectable loyalty and a remarkable adherence to the Catholic tradition.

It is not surprising then that some areas of recruitment have been relatively unproblematic when attempting to attract students to teach in the Catholic sector in Scotland. In an increasingly secular country, where religion and faith are regarded as 'un-cool', the number of students applying for the undergraduate course, to enable them to teach in the Catholic sector, remains strikingly high. Of course, the fact cannot be dismissed that in gaining the Catholic Teachers' Certificate new teachers will have the ability to teach in any school in Scotland, where non-Catholics will for the most part find themselves restricted to the nondenominational sector (this applies to almost all non-Catholic primary teachers). This will be attractive to many potential Catholic applicants and, of course, it is possible to view sceptically students' feedback since environmental and career factors, and incentives, may result in an outward conformity to certain norms and values. In general, teachers might say certain things in the interest of their careers and it is accepted that statements of principle and value are vulnerable to cynical interpretations that reduce them to a set of occupational calculations. There is awareness, then, that evidence is susceptible to a range of interpretations, but there is enough salience in the data to suggest that certain kinds of interpretation are more valid than others. The purpose of this research is to try and see this from a phenomenological perspective-from the inside-investigating the inner motives and desires of the Catholic teacher. So while it might be suggested that students living in a late industrial polity such as modern Scotland see strategic advantages in entering the Catholic sector, there is nothing to suggest that the responses from the students involved in this study are insincere and it is considered that the instrumentation used 
by the researcher in order to gain feedback was sufficiently sophisticated to get to the heart of people's motivations.

The study therefore genuinely illustrates a desire and willingness of students to contribute to Catholic Education, based on a firm belief in the value of their own personal biographies.

\section{Differing faith backgrounds}

Another theme emerging from the interviews was the difference in the response to faith backgrounds of the participants. Although the majority came from practising Catholic families, the difference in their understanding and experience of faith is quite significant. Some indicated being involved in the Church and being active members of related groups and so were constantly engaged in faith discussions and activities. At the other end of the spectrum, some had not been attending Church since they left school and had just recently returned. Although it can be argued that Church attendance is not a prerequisite for an adequate knowledge and understanding of one's faith, it would be reasonable to argue that those regularly involved in the Catholic Church would have a deeper understanding of what it is to be Catholic and be more up-to date with Church developments and teachings. Therefore, the starting positions of these student Catholic teachers are very different and this is evident from the concerns and worries that some of them have articulated in terms of their own knowledge and understanding and experience of their faith. To enter the teaching profession, potential applicants have to produce evidence, usually exam results or certification of a degree award, to indicate that they have achieved a level of academic competence. For those wishing to teach in the Catholic sector a parallel indication of a sufficient level of faith cannot be submitted. Other than a reference from a priest to say that the applicant is known to him and attends Mass, the Church has no way of determining the depth of faith, knowledge and understanding that Catholic teachers possess.

This, then, has implications for consistency in the teaching of RE and the promotion of faith across the sector. If the Church is committed to ensuring that this is a priority in its schools then it would seem reasonable to expect closer monitoring of the faith position of staff during their career in addition to the approval process taking place before they start. There are potential dangers involved in this, particularly with regard to issues of sensitivity regarding what is considered professional development as opposed to something that may be considered private and personal. While some of these concerns have been voiced by the leaders of some Catholic schools in Scotland (Coll, 2006) there is a recognition that the issue requires detailed attention.

\section{Self-perceptions}

What is striking from these interviews is the clear articulation and understanding of what respondents believe their role to be as a Catholic teacher. The vocabulary used 
was indicative of a firm knowledge of the Church's expectation of them and, although they accepted and appreciated the responsibility placed on them, not all felt ready to carry out such a task.

It is very clear that those interviewed place pressure on themselves to be effective Catholic teachers. While most interviewees spoke positively about their faith background, a minority articulated a less than satisfactory experience and when referring to their religious development, or lack of it, rarely the family or parish was criticised-rather, it was the Catholic school. As former pupils of the Catholic sector, reflecting on their faith, there was for some the realisation that the school had not fulfilled its mission in effectively supporting and developing their faithsometimes quite the opposite. This aggrieved some respondents, indicative of their unfulfilled expectation that the Catholic school ought to achieve this. The effect of this is that they have put pressure on themselves to ensure that they carry out their role effectively. What is noticeable, however, is that the negative experiences from their own education in the Catholic school always appear connected to the content of the RE lessons. Some remembered RE being a waste of time owing to teachers' incompetence and others were critical of the knowledge - or rather lack of it - they received during these lessons. Interestingly, when we turn to the concerns that these student teachers have articulated regarding their own ability to be effective Catholic teachers, again these are nearly always concerned with their knowledge base or understanding of Church teachings, and how to communicate this competently to children. It appears that a thorough knowledge and understanding of the RE curriculum in Catholic schools is something in which Catholic teachers require continued support (and perhaps should have had in the past). Without exception, all of the student teachers praised the level of support they had received during their ITE studies in the area of Religious Education and Catholic Teacher Formation but for some, and in particular those on the one-year postgraduate course, this had only given them a foundation on which to build and there was clear recognition that further development was required.

Where the negative experiences of their own Catholic education were concerned with the content of the RE curriculum, the positive experiences were related to the pastoral nature and ethos of the school. The accounts of the supportive teachers, the Christian vocabulary used when working with their classes, the witness to faith in word and action - in addition to experiences of prayer and worship - were examples of positive formative faith experiences and again, this seemed to be the area to which respondents themselves feel ready and able to contribute. For many, the support network at home, and from their parish are considered to be of value in supporting them in this area.

This study revealed that there are two related yet different aspects to the role of the Catholic teacher as identified by the respondents. One appears to be the imparting of information and knowledge and assisting the children in the understanding of Catholic Church teaching through RE lessons. The other is the pastoral role of the teacher, the day-to-day interaction with the children and staff and the promotion of the Catholic faith throughout. The Church itself stresses that RE in 
the Catholic school is not confined to the RE class but rather it should permeate the life and ethos of the school (Sacred Congregation for Catholic Education, 1977, paragragh 50). Nevertheless, when identifying concerns and areas for support and development, many student teachers have diagnosed a lack of knowledge in the subject area of Religious Education and feel more confident in contributing to the faith ethos of the school by their words and actions - being a witness to their faiththroughout the school day.

\section{Continuing professional development}

The students' expectation of development in the area of their own faith, and knowledge and understanding of it, is significant. Without exception, all expressed a need and desire for support in this area and, although unaware of how this would come about, they were relying on it to assist them in their work. Different kinds of support were suggested, ranging from retreats to attending courses, but all of them recognised this to be part of their continuing professional development and something in which staff should engage collaboratively. The majority indicated that this should be formalised, yet all expected an informal constant source of support from their school. What is revealing here is the expectation of the leadership of the schools in which they will find themselves. The assumption that Catholic head teachers ensure that faith development of staff is a school priority is perhaps idealistic. Indeed the Church has stressed the importance of the provision of faith development for Catholic teachers which, according to it, must aim to 'animate them as witnesses of Christ in the classroom and tackle the problems of their particular apostolate'. (Sacred Congregation for Catholic Education, 1977, paragraph 78). However, the commitment of Scotland's Catholic school managers to the continued faith formation of their teachers has been questioned in the past (Coll, 2006) and it has been argued that the different agendas driving CPD in Scotland have resulted in school leaders responding to the demands placed on them by the Government at the expense of focusing on aspects of the faith nature of their school.

These student teachers are well aware of their strengths and weaknesses in relation to their role as Catholic teachers and have identified the areas requiring development at this early stage. They appear to be unrealistic in their expectations of the level of support they will receive from the school, but then Church documentation stresses the importance of their job and directs them to seek support and formation in this aspect of their work (Sacred Congregation for Catholic Education, 1977, paragraphs 78-80). It appears that any formal support network currently in place in schools will fall short of many of these student teachers' expectations, raising questions for the Catholic Church in Scotland and the Scottish Executive to address if Catholic schools are to continue to be supported and funded by the state.

If Catholic schools are a valued part of the Scottish Education system then perhaps more consideration should be given by the major stakeholders to assisting newly qualified teachers to fulfil their role as effective Catholic educators. 


\section{Notes on contributor}

Roisín Coll teaches Religious Education to undergraduate and postgraduate student teachers at the University of Glasgow. Her research interests include comparative education, faith-based education and the continuing professional development of teachers.

\section{References}

Ball, S. J. (2003) The teacher's soul and the terrors of performativity, fournal of Education Policy, 18(2), 215-228.

Bishops'Conference of England and Wales (May 2000) Statement on religious education in Catholic schools.

Boyle, R. \& Lynch, P. (Eds) (1998) Out of the Ghetto The Catholic Community in Modern Scotland (Edinburgh, John Donald).

Bradley, J. (Ed.) (2004) Celtic minded essays on religion, politics, society, identity and football (Argyll, Argyll Publishing).

Coll, R. (2002) Examination of the consultation and development process for the Scottish Catholic religious education guidelines, Catholic Education: A fournal of Inquiry and Practice, 6(2), 233-250.

Coll, R. (2006) Faith formation and CPD for Catholic teachers, fournal of In-Service Education: An International Fournal of Professional Development, 32(4), 431-450.

Conroy, J. C. (2001) A very Scottish affair: Catholic education and the State, Oxford Review of Education, 27(4), 543-558.

Dadds, M. (1997) Continuing professional development: nurturing the expert within, British Fournal of In-Service Education, 23(1), 31-38.

Devine, T. (Ed.) (2000) Scotland's sham: bigotry and sectarianism in modern Scotland (Edinburgh, Mainstream Publishing).

Grace, G. (2002) Catholic schools mission, markets and morality (London, Routledge Falmer).

Gravissimum Educationis (1965) Declaration of the Second Vatican Council on Christian Education, in: W. M. Abbot (Ed.) (1966), The documents of Vatican II (London \& Dublin, Geoffrey Chapman), 637-651.

Great Britain Statutes (1918) Education (Scotland) Act.

Handley, J. (1947) The Irish in modern Scotland (Oxford, Cork University Press).

Hargreaves, A. (1998) The emotional practice of teaching, Teaching and Teacher Education, 14(8), $835-54$.

Levin, B. (1998) An epidemic of education policy: what can we learn for each other? Comparative Education, 34(2), 131-142.

McMillan, J. (2000) Scotland's shame, in: T. Devine (Ed.). (2000), Scotland's shame bigotry and sectarianism in modern Scotland (Edinburgh, Mainstream Publishing).

Mills, M., Martino, W. \& Lingard, B. (2004) Attracting, recruiting and retaining male teachers: policy issues in the male teacher debate, British fournal of Sociology of Education, 25(3), 335-369.

O'Hagan, F. (2006) The contribution of the religious orders to education in Glasgow during the period 1847-1918 (Lampeter, Edwin Mellen Press).

Patton, M. (1990) Qualitative evaluation and research methods (Newbury Park, CA, Sage).

Quality Assurance Agency (2000) Quality assurance in initial teacher education: the standard for initial teacher education in Scotland.

Sacred Congregation for Catholic Education (1977) The Catholic school.

Sacred Congregation for Catholic Education (1982) Lay Catholics in schools: witnesses to faith (London, Catholic Truth Society). 
Sacred Congregation for Catholic Education (1998) The Catholic school on the threshold of the third millennium.

SCES (online) web site http://www.sces.uk.com/Teaching/Default.asp (accessed 12 January 2007).

Short, G. (2002) Faith-based schools: a threat to social cohesion?, fournal of Philosophy of Education, 36(4), 559-572.

SOED (1994) Religious education 5-14 Roman Catholic schools.

Strauss, A. \& Corbin, J. (1998) Basics of qualitative research (London, Sage).

Thornton, M., Bricheno, P. \& Reid, I. (2002) Students' reasons for wanting to teach in primary school, Research in Education, 67, 33-43.

Voiels, V. (1996) The inner self and becoming a teacher, in: M. Steiner (Ed.). (1996), Developing the global teacher: theory and practice in initial teacher education (Staffordshire, Trentham Books Limited), 153-161.

Wengraf, T. (2001) Qualitative research interviewing (London, Sage).

Younger, M., Brindley, S., Pedder, D. \& Hagger, H. (2004) Starting points: student teachers' reasons for becoming teachers and their perceptions of what this will mean, European fournal of Teacher Education, 27(3), 245-264. 